DOI https://doi.org/10.36059/978-966-397-121-6/39-59

\title{
THE SCENE OF THE CRIME AS AN OBJECT FOR RESEARCH
}

\section{Dyntu V.}

\section{INTRODUCTION}

Criminal offenses are the most negative, immoral and generally dangerous phenomenon in the life of modern society. They cause destructive consequences for the state, society and a particular person. Criminal activity significantly influences on all social institutions, thus determining the dysfunction of them. The social and economic crisis that has recently been observed in the Ukraine, has led to the emergence of a number of factors, which cased a steady rise of the number of criminal offenses, thus consequently the issues of crime combating have become particularly relevant.

These factors predetermine the necessity for further in-depth study of criminal activity which aids to improve the effectiveness of the recommendations for its detection, investigation and prevention.

One of the most important elements of the crime mechanism is the crime scene. It is a mandatory element of the crime mechanism since any crime is committed in conditions of objective reality which significantly affect the behavior of the offender and the mechanism of trace formation. Knowledge of certain types of crime scene from certain categories of crimes allows investigator or other authorized person to submit valid versions and simulate the situation for a specific crime, which is investigating and to distinguish its features. Knowledge of relationships and dependencies of the crime scene and other circumstances of the crime contributes to establishing a genuine and complete picture of the crime.

The imperfection of the theoretical development of the doctrine of the crime scene and its place in criminalistics negatively affects the state of criminalistics in general, and on the direct application of existing scientific developments, methods and practical recommendations in crime investigation. 
The above suggests that the doctrine of the crime scene as a significant concept of criminalistics currently is extremely relevant and practically in demand which led to the choice of research topic.

\section{The Usage of Data About the Crime Scene in the Cognitive Activity of Investigator}

Cognition as an activity is realized through the system of cognitive means: sensory observation; everyday practice; experiment; models; mathematical apparatus; methodological basis ${ }^{1}$.

Cognition of the crime is a complex mental activity that encounters certain difficulties, which are related to the mediation of the knowledge of the events of the past through the prism of the results of reflecting the circumstances of the crime in the environment.

In legal literature it has been repeatedly noted that the investigation of a crime in its content is a kind of cognitive activity ${ }^{2}$.

Cognition is the process of obtaining, comprehending and using information, through which knowledge is formed in relation to an object that is scrutinized ${ }^{3}$. Implicit reproduction based on the collected actual data of a coherent picture of the accomplished and its consequences for all essential criminalistic and legally significant features forms the general cognitive task of criminal proceedings ${ }^{4}$.

The cognitive essence of criminal-procedural knowledge consists in the retrospective disclosure (knowledge) of the individual aspects of the events of the past and the establishment on this basis of objective truth ${ }^{5}$.

The specifics of criminal procedural cognitive activity consists of the fact that the investigation body examines interconnections directly perceive phenomena, as well as those that are reflected in the minds of people. In the first case natural phenomena and patterns are investigated,

${ }_{1}^{1}$ Андреев И. Д. Основы теории познания. М. : Изд-во АН СССР, 1959. С. 177.

2 Проблема связей и отношений в материалистической диалектике / отв. ред. Тюхин В. С. М. : Наука, 1990. С. 23; Медведев Н. Н. Теоретические основы расследования. Краснодар : Кубан. гос. ун-т, 1977. С. 4-24; Якубович Н. А. Теоретические основы предварительного следствия. М. : ВШ МВД СССР, 1971. С. 48-49; Белкин Р. С. Криминалистика и доказывание (методологические проблемы). М. : Юридическая литература, 1969. С. 8-12.

${ }^{3}$ Коновалова В. Е. Правовая психология : учебное пособие. Х. : Основа, 1990. C. 58.

${ }^{4}$ Криминалистика / под редакцией Образцова В. А.. М. : Юрист, 1995. С. 69.

${ }^{5}$ Образцов В. А. Основы криминалистики. М. : Юристь, 1996. С. 13. 
while objectively determined tasks are solved. In the second case, the laws of the psyche of humans, their emotions, desires and intentions are investigated, therefore subjectively determined "riddles"6.

In the opinion of O. I. Trusov, which would have no significant specificity of proof, it is nothing more than a kind of cognitive activity, since its purpose is to establish the truth ${ }^{7}$.

In conducting an investigation, the investigator acquires certain knowledge of the crime committed, guilty person and on this basis makes conclusions, makes appropriate decisions. The knowledge of the facts of objective reality permeates all the activities of the investigator in the criminal process ${ }^{8}$.

It must be taken into account that the investigation has a research nature, therefore, it uses not only empirical but also theoretical means of cognition ${ }^{9}$. Thus, in a criminal proceeding, the investigator applies both empirical and theoretical means by which he learns the event that has occurred. R. S. Belkin and A.I. Wienberg noted that the classification of methods of science and practice on empirical and logical (theoretical) is very conditional. Any empirical method is not possible without meaningful human activity, without setting the task and processing the results. Similarly, logical cognition is impossible without a sensory element ${ }^{10}$.

Empirical is a level of knowledge that is realized, mainly, on the sensual level, thus, due to the direct interaction of the senses with the environment. The empirical level of knowledge explores the object from its external manifestations, features and properties available at the level of perception.

With regard to empirical knowledge, it can be argued that it is carried out by the investigator in the course of conducting the relevant

${ }^{6}$ Берназ В. Д. Понятие следственной деятельности: криминалистические и психологические аспекты. Вісник НУВС. 2003. № 21. Ч. 1. С. 65-72; Стратонов В. М. Криміналістична теорія пізнавальної діяльності : монографія. Х. : Вид-во Херсон. держ. ун-ту, 2009. С. 231.

7 Трусов А. И. Основы теории судебных доказательств. Краткий очерк. М. : Госюриздат, 1960. С. 9.

8 Лузгин И. М. Расследование как процесс познания : учебное пособие. М., 1969. C. 11.

9 Проблема связей и отношений в материалистической диалектике / отв. ред. Тюхин В. С. М. : Наука, 1990. С. 69.

${ }^{10}$ Белкин Р. С. Криминалистика и доказывание. М. : Юридическая литература, 1969. С. 26. 
investigative actions, since the initial knowledge of the crime and the circumstances of the crime investigator occurs precisely at the sensory level of perception of information. Empirical cognitive techniques such as observation, measurement, experiment, and others are effectively used by the investigator to search, detect, research, and use relevant information.

During the investigation, it is possible with the help of specially developed theories, methodologies, methods, principles to investigate and analyze not only external but also internal properties of the object of research, to comprehend its essence and content.

The investigator also applies the theoretical level of knowledge, since in his work uses all the techniques, methods and means of research of realities of reality that are proposed by science. The rationality and degree of effectiveness of using theoretical achievements depends on the level of education and intellectual ability of the investigator.

For tasks of practical life and for scientific knowledge, V.F. Asmus noted that it is important, that out of all the enormous set of subject properties, our though highlights the most important and noticeable, in such a way that each of the features was absolutely necessary, and all the signs taken together would be sufficient for them to distinguish this object from all others, to scrutinize this subject ${ }^{11}$.

During the investigation the research of each crime situation can be considered as part of the final task correlated with the establishment of the subject of evidence, as well as an indirect task which solving helps to clarify other circumstances of the crime. As already mentioned, material situation - this is the situation with which the investigator encounters, first and foremost, which allows him to put forward versions of the method of crime, the behavior of the offender and other circumstances. However, knowledge of the situation of a crime is a difficult task, since not all of its elements are obvious, especially with regard to which the perpetrator committed measures of staging and distortion of the actual circumstances of the event. Therefore, the situation of the crime in all its forms continues to be scrutinized throughout the investigation.

${ }^{11}$ Асмус В. Ф. Логика. Изд. 2-е, стереотипное. М. : Едиториал УРСС, 2001. С. 32. 
According to generalization of the views of criminalists ${ }^{12}$ it can be argued that cognitive activity of the investigator on the nature and circumstances of the crime, in particular, its environment the situation has certain features that distinguish it among other types of knowledge:

firstly, the cognitive activity of the investigator, has a retrospective character, in particular is intended to recreate an event that has taken place in the past on the basis of information that is encrypted in the context of scene of the crime; however, it should be noted that scrutiny of the crime scene also provides an opportunity for forecasting developments of the further event, when its research is conducted within the framework of investigating the repetition of the crime. Then information about the typical scene of crime in which the offender made preparation, commit and conceal the crime gives an opportunity to predict his further actions and the conditions in which he will implement them;

secondly, the cognitive activity of the investigator is characterized by a limited amount of information regarding the crime scene which at the beginning of the investigation has fragmentary character and has low level of reliability;

thirdly, such activity is aimed at establishing an objective picture, namely, is finding out all the circumstances of a criminal incident by examining the circumstances of a crime;

fourthly, the cognitive activity of the investigator is aimed at investigating the circumstances of the crime in the totality of its elements (place, time, other conditions) which are interconnected, so that knowledge has a systemic and structural character;

fifthly, knowing the circumstances of the crime is an intermediate object through which other circumstances of the crime are learned - the ultimate object of cognition in the investigation.

We can agree with the opinion of I. M. Akimov, who noted that, careful, thoughtful study of the crime scene like introducing into the atmosphere of a crime which is reflected in the environment and not so much visible as it is felt and guessed. Penetration into the essence of the crime scene leads to a clear understanding of what happened to

12 Котюк I. I. Теорія судового пізнання : монографія. К. : Видавничополіграфічний центр «Київський університет», 2006. С. 100; Стратонов В. М. Криміналістична теорія пізнавальної діяльності : монографія. Х. : Вид-во Херсон. держ. ун-ту, 2009. С. 30; Тіщенко В. В. Теоретичні і практичні основи методики розслідування злочинів : монографія. О. : Фенікс, 2007. С. 90. 
the comprehension of the inner connection between actions which were committed by a criminal will and their display outside. Such an understanding enables not only mentally to reproduce the picture of a crime, but also to understand the motives that guided the offender while committing the crime. Thus it becomes the key to the crime solving ${ }^{13}$.

Currently in the criminalistics, there are two approaches to understanding the circumstances of the crime.

In the narrow sense, it is the place of the crime, which is serving as a system of the material world objects, in which the crime was committed and which is the bearer of information regarding the event, what appeared in it in the form of reflection.

It should be said that a narrow approach to understanding the scene of the crime was typical for the early period of criminalistics was typical for the early period of criminalistics when the scene of the crime was identified with the notion of the place of the crime

It should be noted that aforementioned approach restricts the possibility of studying the issue under study, since it takes for the original value only reflected in objective reality material constituent of a criminal events and leaves out the attention other significant elements which are an integral part of the structure of the crime scene and characterize the system of conditions in which actions were of preparation and concealment of a criminal offense were taken.

Identifying the concepts of "crime scene" and "crime place" leads to narrowing the content of the latter, and as a consequence of the incorrect perception of its essence. It should be said that the scene of crime is a broader concept than the place of crime, since the crime scene is not only a system of objects of the material world which contains a mapping of the crime event but also information regarding conditions in which the crime was being prepared, external factors which contributed or prevented the events of the crime, the circumstances under which the process of concealing the crime took place.

Depending on the significance of the investigation V. I. Kulikov identified three situations in which can be used the information about the scene of crime: information about the scene of crime is considered as an

13 Якимов И. Н. Криминалистика : Руководство по уголовной технике и тактике (репринт. изд. 1925 г.). М. : ЛексЭст, 2003. С. 192-193. 
additional source of evidence, what is available in the criminal proceedings; information about the crime scene become equivalent to another source of evidence, information about the scene of crime becomes the only available source of forensic information the circumstances of the crime and the persons who committed it ${ }^{14}$.

From the above it is seen, that, depending on each particular situation, the information, which is in the context of a crime scene acquires different significance in the investigation.

The crime scene consists of material, microsocial and moralpsychological environment in which actions to prepare, implement and conceal the crime were taken. It should be noted, that the mentioned structure of the crime scene, depending on the type of crime can be truncated and consist of only two elements micro-social and moralpsychological environment.

Triple element of the crime scene which is typical for all kinds of crime, except for crimes, which are characterized by two elemental composition, for example: the involvement of underage in criminal activity, threat of murder and others which do not contain the material crime scene.

\section{Programming of the Investigation Process with the Aid of Information About the Scene of the Crime}

The initial activity of the investigator is to establish the fact of committing a crime or preparing for it. The above classification will enable the investigator during the detection a certain type of crime to establish the necessity for research material, microsocial or moralpsychological environment. Thrs, when the investigator found that the actions had been committed, in which there are signs of a crime, for instance, avoidance of child support payments, the investigator concludes that it is necessary to carry out a thorough study of microsocial environment, in particular, the relationship between the offender and the victim.

${ }^{14}$ Куликов В. И. Обстановка совершения хищения государственного и общественного имущества как объект специального криминалистического исследования. Методика и психология расследования хищений государственного и общественного имущества : сб. науч. тр. Свердловск, 1986. С. 50. 
The demands of practice in optimizing investigative activities, the rise of the theoretical level of the investigation process predetermine the necessity of formalization the investigation of crimes ${ }^{15}$.

We can agree with the opinion of M.O. Selivanov, who indicated that especially the broad possibilities of the formalization method in the development of typical programs for solving individual problems of investigation which can be conventionally called partitive programs. If general programs reflect more or less complete methods of investigating certain types of crimes, then partitive are designed to solve local investigative tasks - construction versions, establishing a method of committing or concealing a crime, causes and conditions which aids it, searching for a criminal or the abduction of values and etc. ${ }^{16}$.

Methodology of the formal description of the information structure of the investigation in the form of a hierarchical construction of interrelated events which integrated into a holistic system of the activity of investigation of crimes, and the preparation and commission of crimes ${ }^{17}$.

It should be noted, that at the present stage of development of criminalistics scholars began to make suggestions about the necessity for development and implementation into practical activity programs and algorithms of the investigator's actions, which are aimed at optimizing and rationalizing the investigation process ${ }^{18}$.

V.A. Zhuravel points out, that criminalistic programs and algorithms must be considered the most appropriate form of adaptation

${ }^{15}$ Шевчук В. М. Тактичні операції у криміналістиці: тактичні засади формування та практика реалізації : монографія. Х. : Вид. агенція «Апостіль», 2013. C. 299.

${ }^{16}$ Образцов В. А. Криминалистическая характеристика преступлений: дискуссионные вопросы и пути их разрешения. Криминалистическая характеристика пре ступлений : сб. науч. трудов. М., 1984. С. 62-63.

${ }^{17}$ Шаров В.И. Формализация в криминалистике. Вопросы теории и методологии криминалистического исследования : автореф. дис. ... докт. юрид. наук. Нижний Новгород, 2003. С. 9.

18 Журавель В. Формалізація розслідування : теоретичні основи і практичні можливості. Правн. часопис Донец. нац. ун-ту. Донецьк, 2010. № 1 (23). С. 100; Ищенко Е. П. Алгоритмизация следственной деятельности : монографія. М. : Юрлитинформ, 2010. С. 50; Тіщенко В. В. Теоретичні і практичні основи методики розслідування злочинів : монографія. О. : Фенікс, 2007. С. 176. 
of methodological and forensic recommendations to the terms of investigation of a particular crime ${ }^{19}$.

The optimization of the process of investigating a crime is seen in the application of the program-target method which is targeting to develop relevant investigation programs ${ }^{20}$.

For the first time the concept and content of the program-target method was defined by G. A. Gustov. He pointed out that programtargeting method is one of the methods of organizing and managing the investigation process. Under it is understood a scientific analysis, organization of investigation and receipt of new knowledge in the criminal case with the aid of pre-designed typical forensic programs ${ }^{21}$.

S.Yu. Chuzhikov by the method of program-targeted investigation understands "organization of the leadership of the investigation process which is caused by the regularity of a criminal event, investigation activities and crime scene, in which it is conducted a technological system of typical programs and algorithms (rules and operations), which proper implementation helps to optimize the work of law enforcement officials and guarantees receipt of criminal cases of new knowledge (evidence) for timely and correct solution of the tactical tasks of the preliminary investigation",22.

G.O. Zorin quite rightly noted, that programming as a method of rationalizing the investigation and optimizing the planning of the investigation, the contents of which are programs which is aimed at

${ }^{19}$ Густов Г.А. Программно-целевой метод организации раскрытия убийств : учебное пособие. Институт повышения квалифик. прокурорско-следственных работников Прокуратуры РФ СПб, 1993. С. 94.

${ }^{20}$ Кузнецов П. С. Отсутствующие следы и отсутствие следов (гносеологический и онтологический аспект). Российский юридический журнал. 2009. № 3. С. 186; Бурданова В.С. Программа раскрытия убийств, совершенных по найму. Южно Уральские криминалистические чтения. Уфа[б.и.], 1999. С. 13; Шаталов А.С. Криминалистические алгоритмы и программы. Теория. Проблемы. Прикладные аспекты. М. : Лига Разум, 2000. С. 124; Кузьмин С. В. Программно-целевой метод организации расследования краж. Проблемь предварительного следствия $u$ дознания : сборник научных трудов. М. : Изд-во ВНИИ МВД РФ, 1994. С. 23.

${ }^{21}$ Густов Г. А. Программно-целевой метод организации раскрытия убийств : учебное пособие. Институт повышения квалифик. прокурорско-следственных работников Прокуратуры РФ СПб, 1993. С. 7.

22 Чужиков С. Ю. Программно-целевой метод в расследовании преступлений, совершенных в условиях неочевидности: Актуальные проблемы юридической науки. Татищевские чтения : актуальные проблемь науки и практики : Актуальнье проблемы юридической науки : материалы V юбилейной международной научнопрактической конференции. Тольятти : ВУиТ, 2008. Ч. 4. С. 219-225. 
determining the current situation, finding out the tasks of investigation and selecting the means to achieve them ${ }^{23}$.

According to I.O.Vozgreen, program (algorithm) of investigation is a system of information on the sequence of investigative actions which are most typical for the investigation of this category of criminal cases. Such programs are being developed for different stages of investigation by investigative situations which is the most commonly encountered however, taking into account a number of factors ${ }^{24}$.

We can agree with the opinion of E.P. Ishchenko, , who indicates that a set of tactical tasks, which are specified by subject of proof forms the basis of the program-target complex, which, directs the tactical activity of the investigator suring working with the source of evidence and making procedural decisions ${ }^{25}$.

As V.O. Konovalova emphasizes, in the methodics of investigation of certain types of crimes an important place belongs to tactical operations where they have significant efficiency especially in such circumstances of the investigation, where organization and efficiency are necessary and, where the loss of at least one of the components of such an operation threatens its failure. Therefore, the formulation of these operations would be useful in the form of algorithms for tasks, identified by the investigator in typical investigative situations ${ }^{26}$.

It should be noted that the whole process of investigation of the crime, and the actions of the investigator directed to the knowledge of its particular circumstances.

The scene of crime is a significant source of forensic information which detection should be carried out through a specified program of action.

To achieve the objectives of the study of the crime scene and successful solving of tasks which pointed out to investigator in criminalistics there should be a unified system of scientific provisions

23 Зорин Г. А. Криминалистическая методология. Минск : Амалфея, 2000. C. $145-146$.

24 Возгрин И. А. Научные основы криминалистической методики расследования преступлений. СПб. : [б.и.], 1993. Ч. IV. С. 21.

${ }^{25}$ Ищенко Е. П. Криминалистика: Курс лекций. М. : Юридическая фирма «КОНТРАКТ»; АСТ-МОСКВА, 2007. С. 176.

26 Коновалова В. О. Ефективність реалізації алгоритмів у методиці розслідування злочинів. Правові засади підвищення ефективності боротьби зі злочинністю в Україні : матер. наук. конф., 15 трав. 2008p. Х. : Право, 2008. С. 170-172. 
and practical recommendations based on them, in the form of a study program of the crime scene.

Study program of the crime scene is a system of recommendations for the systematization of tasks, methods and actions of an investigator to achieve the purpose of the investigation by solving specific problems which aimed at detecting, analysis and fixation of criminalistically important information the source of which is the environment where crime was preparing, committing and concealing.

The structure of the program consists of the following elements:

1) the purpose of investigating the crime scene;

2) the task of studying of the crime scene;

3) means and methods for investigating the crime scene.

In order to implement a crime investigation program, it is necessary to determine the goals of its knowledge.

"The operation of the notion of" the purpose of cognitive activity" makes it possible to distinguish in the object of cognition those sides and properties that satisfy the particular cognitive need of the subject"27.

As S.A. Shafer noted, the goal is an ideal image of a result of activity that is ahead of the activity itself ${ }^{28}$. The literature indicates that, to some extent, the target may act as a system-generating factor ${ }^{29}$.

The objectives of knowing of the crime scene can be divided into basic and additional. It should be noted that the purpose of knowing of the crime scene coincides with the purpose of the investigation in general - establishing of the crime scene.

For additional purposes, knowledge of the crime scene can be attributed:

a) extraction of forensic-sensitive information from the investigated object in relation to other circumstances of the event and the persons who took part in it;

b) detection of new circumstances relevant to criminal proceedings;

c) checking available information in criminal proceedings.

27 Князьков А. С. Об уголовно-процессуальном и криминалистическом понимании целей и задач следственного действия. Вестник Томского государственного университета. 2011. № 347 С. 100.

${ }^{8}$ Шейфер С. А. Следственные действия. Система и процессуальная форма. М. : Юрлитинформ, 2001. С. 18.

${ }^{29}$ Андреев И. Д. Теория как форма организации научного знания. М. : Наука,1979. С. 9-10. 
The purpose is a real or ideal object of conscious or unconscious desire of the subject; the final result on which the process is intentionally directed. The achievement of the above result becomes possible by solving the tasks set before the investigator.

During investigating the crime scene investigator should set and solve a system of general and individual tasks. General tasks are those tasks that an investigator must solve after studying the whole system of the crime scene, individual tasks are that the one wchich investigator solves in the study of a particular environment (material, microsocial and moral-psychological).

General ones include the following tasks:

- identify the features of the crime;

- determine the type of crime which was committed;

- determine for which stage of the crime (preparation, realization, concealment) revealed the situation of the crime is typical;

- to determine the material, microsocial and moral-psychological environment in which the crime was committed;

- to determine whether the crime was committed spontaneously or its implementation was preceded by a stage of training;

- to identify changes in the crime scene that are not related to the crime;

- to determine the elements of the crime scene that are related to the crime;

- to identify the elements of the crime scene which are containing forensic information;

- to determine the presence or absence of signs of staging a crime scene;

- to identify the factors that led to the change or damage the crime scene (climatic conditions, actions of persons, etc.);

- to identify persons who caused changes in the crime scene (offender, victim, witness);

- to determine the connection of the crime scene with the method of committing a crime (which means, implements and other accessories were used to commit a crime);

- to determine the connection between the crime scene and the person of the offender;

- to determine the nature of the actions committed by the offender in the context of the crime, their algorithm and consistency; 
- to determine whether the witnesses were at the time of committing the crime, the nature of their actions;

- to determine the behavior of the victim, whether they have committed acts of resistance to the offender;

- determine the connection of the crime scene with the object of the crime.

Individual tasks which should be solved by the investigator in the study of the material environment:

- to identify and fixate the system of material objects available at the time of the research;

- to identify the climatic conditions in which the crime was committed;

- to set the time, spatial characteristics of the crime scene

- to determine the source of the object's origin and the logic of its availability in the investigated crime scene;

- to identify the personal and imported features of the object;

- to determine the places of the object at the time of the commission of the crime and to commit a crime, its before criminal characteristics;

- to establish the influence of the offender on a set of objects, which make up the system of the environment and establish its nature;

- to identify and fix material traces;

- to determine the absence in the environment of the crime of material objects, which must be in it under normal conditions of its existence;

- to determine the carriers of information about the method of crime, the object of the crime and the identity of the offender and their research, analysis;

- to determine the manner in which the crime was committed, tools and means which where used to commit the crime;

- to determine the object of a criminal offense, its features and qualitative characteristics;

- to find out the identity of the offender, his characteristics, the nature of his behavior;

- to figure out the identity of the victim and the witness, their characteristics and behavior.

Individual tasks which should be solved by the investigator in the study of microsocial environment: 
- establishment of information on the circumstances of the case;

- establishment of information regarding the material environment in which the crime was prepared, committed and concealed, its qualitative and quantitative characteristics;

- establishment of means by which a criminal result was achieved;

- establishment of circumstances conducive to the commission of a crime; which complicated the commission of a crime and the ways of overcoming it by a criminal;

- establishment of information about the offender's identity;

- establishment of motives for committing a crime;

- establishing information about the offender's relations with other people, labor, collective, service, family relationship, other information, which characterize the offender, as part of society and can explain the determinants of his behavior;

- establishment of information about the relationship of the offender with the victim, the presence of a conflict situation;

- establishing information on the method of crime, the object of the attack.

The study of the moral and psychological environment provides the opportunity to establish moral and psychological conditions in which there were participants of the crime in the preparation, implementation and concealment of a crime.

Individual tasks which should be solved by the investigator in the study of moral and psychological environment:

- to determine the moral and psychological conditions in which the process of preparation, realization and concealment of a crime proceeded;

- to identify the moral and psychological circumstances that contributed or prevented the process of preparation, implementation and concealment of the crime;

- to determine the moral and psychological relations between the perpetrator and the victim;

- to determine the moral-psychological relationship between the offender and other actors of the crime.

The solution of the above tasks will enable the investigator to obtain information regarding the occurrence of the criminal event in conditions which they are being investigated, the person of the offender, the way in which the crime was committed, the object encounter, to determine valid 
versions and to make decisions and decide regarding the planning of the further investigation.

Effective application of the crime investigation study program is possible with the aid of the step-by-step task solving the tasks facing the investigator. Efficiency and rationality of problem solving depends on the system of successive actions aimed at investigating the crime.

Investigation of the crime scene as an object of knowledge becomes possible by using the system of means of cognition, which are established by procedural legislation - investigative (searches) actions and the secret investigator (searches) actions, as well as through operational-search activities which are provided by the relevant law. The system of means by which the knowledge of the crime scene is carried out is the unity of certain components, which are interconnected with each other and constitute a sustainable organization. Means of knowledge of the crime scene have the same object of knowledge. They are combined for the similar purpose - establishing the circumstances of a criminal offense for its effective and prompt investigation.

\section{CONCLUSIONS}

For criminalistics has interest the study of the properties of the person, which determine the processes of preparing, committing and concealing a crime, as well as has the features to be displayed in the environment, thud while interacting with other elements of the environment to cause the appearance of the effect of each other. Since the person of the offender directly interacts with the environment, in the commission of a crime, for criminalistics is also of interest to study the environment, in particular the scene of crime.

The crime sscene and the person of the offender as elements of a united structure of the crime are in mutual dependence and linked by relevant links at the stage of preparation for a crime, his commission and subsequent concealment.

The environment in which the offender is located indirectly or directly influences his behavior. The situation of the crime determines the behavior of the offender, affects the decisions that offender takes, participates in the formation and change of motive, intent, directs his actions.

It should be noticed that the offender also affects the crime scene. During the preparation for a crime the person of the offender is studying 
and assesses the scene of crime and shapes its model for the future, in other words, makes a forecast. If the crime scene and its predicted model are in line with the requirements for a successful criminal offense the offender will commit the crime without significant change in the crime scene.

If the crime scene is unfavorable for the commission of the crime, the offender will take action on its conversion changes to create favorable conditions for committing a criminal act. In case the change in the unfavorable the crime scene is impossible the offender may refuse to commit a crime at all.

Also, acting in the crime scene the offender leaves in it the results of the interaction which changes its original state. Investigation of the crime scene gives opportunity to get information about the person of the offender, the features of his character, criminal qualification, mental health and other information which make it possible to identify the person who committed the crime.

Knowledge of the crime scene investigator occurs at the empirical and theoretical levels. The investigator discovers the environment in which the crime was committed, carries out its research, finds criminolistically meaningful information, defines the relationship with other circumstances of the crime. Thus, the crime scene during conducting a pre-trial investigation serves as the object of knowledge which is entering into the interaction with the subject of knowledge (investigator or other authorized person) provides the ability to detect and record information, which matters for crime investigation.

In realizing the scrutiny of the crime scene the investigator should use a certain program of its research, in particular a system of recommendations for systematization of tasks, methods and actions of an investigator to achieve the purpose of the investigation by solving specific problems aimed at detecting, analyzing and fixing criminolistically meaningful information the source of which is the environment in which the crime was prepared, committed and concealed.

The study program of the crime scene consists of the following elements:

a) the objectives of investigating of the crime scene;

b) tasks of investigation of the crime scene;

c) methods and means for investigating of the crime scene.

The main purpose of the study of the crime scene is to establish the circumstances of the crime. 
Additional objectives of the study of the crime scene include the following:

a) obtaining criminolistically meaningful information from the investigated object in relation to other circumstances of the event and the persons who took part in it;

b) identification of new circumstances that are relevant for criminal proceedings;

c) checking available information in criminal proceedings.

During investigating the crime scene, the investigator should set general tasks, which determine the direction of investigation of the whole crime scene. Moreover, investigator should set certain tasks to be solved in the study of the relevant environment, which is part of the internal structure of the crime scene (material, microsocial and moralpsychological).

As a means by which research of crime scene is carried out the investigator uses directly the appropriate investigative actions, as well as operational-search activities.

To obtain a coherent picture of the conditions in which the crime was committed for a comprehensive and complete investigation of the crime scene the investigator should use a systematic approach to conducting investigative actions. The system which is used by him should be clearly formed, planned and carried out according to a certain algorithm.

System in the application of appropriate means of investigating the crime scene will provide an opportunity for their rational and effective use in order to obtain criminolistically meaningful information crime investigation.

The scene of a crime includes a set of information that forms a certain information environment in the investigation of which an investigator forms an evidentiary basis, which is necessary to investigate the crime and establish its appropriate circumstances.

Depending on the nature of the information containing the crime scene, its sources, ways of detection and fixing it can be defined as evidence. Thus, the crime scene can act as a system that is the bearer of evidential information.

Thus, the commission of each crime is accompanied by a certain set of realities of reality, which directly or indirectly influence all stages of the implementation of a criminal act. It is the crime situation, as a 
complex category, which includes in its composition a number of interrelated elements, allows forming a holistic perception of a set of conditions, in which a crime was committed.

\section{SUMMARY}

The importance of information about the crime scene for crimes investigation is considered in the article. The significance of the data about crime scene for the cognitive activity of the investigator is scrutinized. Moreover, the importance of data about the crime scene for the construction of the versions and planning of the investigation is mentioned. The definition of the scene of crime and its significance for criminalistics science is disclosed. The significance of the algorithmic activity of the investigator is considered. The programe of crime scene scrutiny by the investigator is proposed. The structure of the program and methods of its application is established.

\section{REFERENCES}

1. Андреев И. Д. Основы теории познания. Москва : АН СCCР, 1959. $358 \mathrm{c}$.

2. Проблема связей и отношений в материалистической диалектике / отв. ред. Тюхин В. С. Москва. : Наука, 1990. 288 с.

3. Медведев Н. Н. Теоретические основы расследования. Краснодар : Кубан. гос. ун-т, 1977. С. 22-26.

4. Якубович Н. А. Теоретические основы предварительного следствия. Москва : ВШ МВД СССР, 1971. 128 с.

5. Белкин Р. С., Винберг А. И. Криминалистика и доказывание (методологические проблемы). Москва : Юридическая литература, 1969. $216 \mathrm{c.}$

6. Коновалова В. Е. Правовая психология : учебное пособие. Харьков : Основа, 1990. 198 с.

7. Криминалистика / под ред. Образцова В. А.. Москва : Юрист, 1995. 592 с.

8. Образцов В. А. Основы криминалистики. Москва : Юристъ, 1996. $160 \mathrm{c}$.

9. Берназ В. Д. Понятие следственной деятельности: криминалистические и психологические аспекты. Вісник НУВС. 2003. № 21. Ч. 1. С. $65-72$. 
10. Стратонов В. М. Криміналістична теорія пізнавальної діяльності. Харків : Вид-во Херсон. держ. ун-ту, 2009. 440 с.

11. Трусов А. И. Основы теории судебных доказательств. Краткий очерк. Москва : Госюриздат, 1960. 176 с.

12. Лузгин И. М. Расследование как процесс познания : учебное пособие. Москва, 1969. 177 с.

13. Проблема связей и отношений в материалистической диалектике / отв. ред. Тюхин В. С.. Москва : Наука, 1990. 288 с.

14. Белкин Р. С., Винберг А. И. Криминалистика и доказывание (методологические проблемы). Москва : Юридическая литература, 1969. $216 \mathrm{c}$.

15. Асмус В. Ф. Логика. Изд. 2-е, стереотипное. Москва : Едиториал УРСС, 2001. 392 с.

16. Котюк I. I. Теорія судового пізнання. Київ : Видавничополіграфічний центр «Київський університет», 2006. 435 с.

17. Тіщенко В. В. Теоретичні i практичні основи методики розслідування злочинів. Одеса : Фенікс, 2007. 260 с.

18. Якимов И. Н. Криминалистика : Руководство по уголовной технике и тактике (репринт. изд. 1925 г.). Москва : ЛексЭст, 2003. $496 \mathrm{c}$.

19. Куликов В. И. Обстановка совершения хищения государственного и общественного имущества как объект специального криминалистического исследования. Методика и психология расследования хищений государственного и общественного имущества : сб. науч. тр. Свердловск, 1986. С. 44-51.

20. Шевчук В. М. Тактичні операції у криміналістиці: тактичні засади формування та практика реалізації. Харків : Вид. агенція «Апостіль», 2013. 440 с.

21. Образцов В. А. Криминалистическая характеристика преступлений: дискуссионные вопросы и пути их разрешения. Криминалистическая характеристика преступлений: сб. науч. трудов. Москва, 1984. 98 с.

22. Шаров В. И. Формализация в криминалистике. Вопросы теории и методологии криминалистического исследования: автореф. дис. докт. юрид. наук: 12.00.09. Нижний Новгород, 2003. $54 \mathrm{c}$. 
23. Журавель В. Формалізація розслідування : теоретичні основи і практичні можливості. Правн. часопис Донеи. нац. ун-ту. Донецьк, 2010. № 1 (23). С. 100-102.

24. Ищенко Е. П., Водянова Н. Б. Алгоритмизация следственной деятельности. Москва : Юрлитинформ, 2010. 304 с.

25. Густов Г.А. Программно-целевой метод организации раскрытия убийств : учебное пособие. Институт повышения квалифик. прокурорско-следственных работников Прокуратуры РФ СПб, 1993. $122 \mathrm{c.}$

26. Кузнецов П. С. Отсутствующие следы и отсутствие следов (гносеологический и онтологический аспект). Российский юридический журнал. 2009. № 3. С. 185-189.

27. Бурданова $\quad$ В. С., Гуняев В. А. Программа раскрытия убийств, совершенных по найму. Южно Уральские криминалистические чтения. Уфа, [б.и.], 1999. С. 12-19.

28. Шаталов А. С. Криминалистические алгоритмы и программы. Теория. Проблемы. Прикладные аспекты. Москва : Лига Разум, 2000. 252 c.

29. Кузьмин С. В. Программно-целевой метод организации расследования краж. Проблемь предварительного следствия и дознания : сборник научных трудов. Москва : Изд-во ВНИИ МВД РФ, 1994. С. 22-28.

30. Чужиков С. Ю. Программно-целевой метод в расследовании преступлений, совершенных в условиях неочевидности: Актуальные проблемы юридической науки. Татищевские чтения : актуальные проблемы науки и практики : Актуальные проблемы юридической науки : материалы $\mathrm{V}$ юбилейной международной научно-практической конференции. Тольятти : ВУиТ. 2008. Ч. 4. C. 218-225.

31.Зорин Г. А. Криминалистическая методология. Минск : Амалфея, 2000. 608 с.

32. Возгрин И. А. Научные основы криминалистической методики расследования преступлений. Санкт-Петербург, 1993. Ч. IV. $80 \mathrm{c}$.

33. Ищенко Е. П. Криминалистика: Курс лекций. Москва: Юридическая фирма «КОНТРАКТ»; АСТ-МОСКВА, 2007. 416 с.

34. Коновалова В. О. Ефективність реалізації алгоритмів у методиці розслідування злочинів. Правові засади підвищення 
ефективності боротьби зі злочинністю в Україні: матер. наук. конф. (15 трав. 2008р.). Харків : Право, 2008. С. 170-172.

35. Князьков А. С. Об уголовно-процессуальном и криминалистическом понимании целей и задач следственного действия. Вестник Томского государственного университета. 2011. № 347. C. $100-105$.

36. Шейфер С. А. Следственные действия. Система и процессуальная форма. Москва : Юрлитинформ, 2001. 208 с.

37. Андреев И. Д. Теория как форма организации научного знания. Москва : Наука, 1979. 303 с.

\section{Information about the author:} Dyntu V.

Ph. D., Associate Professor of Criminalistics Department, National University "Odesa Law Academy» 23, Fontanska Road, Odesa, 65000, Ukraine 